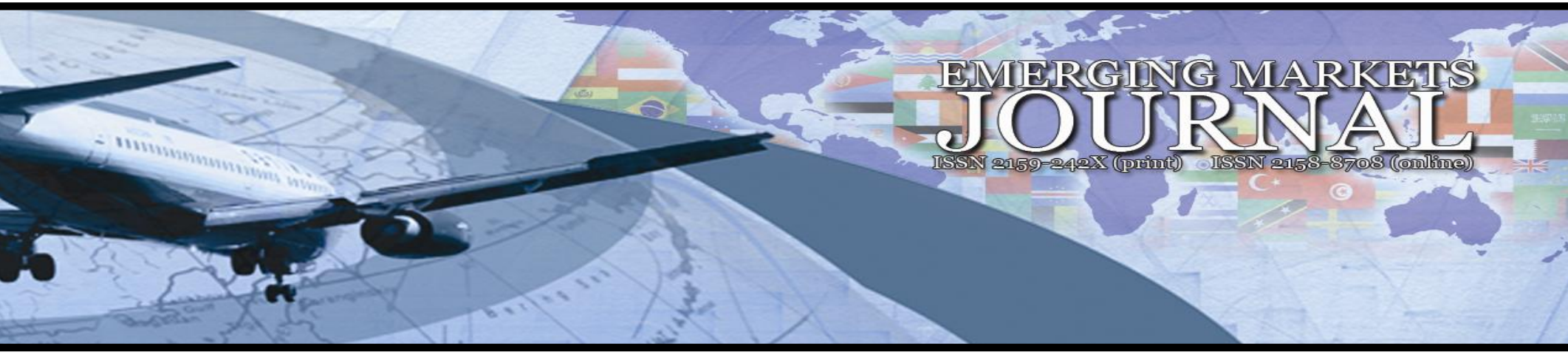

\title{
The Effect of Selected Human Resource Management Practices on Employees' Job Satisfaction in Ethiopian Public Banks
}

\section{Amare Werku Ijigu}

Debre Berhan University, Management Department, College Of Business and Economics, Debre Berhan, Ethiopia, |

email: amarew.john@gmail.com

Volume 5 No 1 (2015) ｜ＩSSN 2158-8708 (online) ｜ DOI 10.5195/emaj.2015.64 | http://emaj.pitt.edu |

Abstract

Most of the research has been conducted in the job satisfaction of employees' on employees job related outcomes but there is little well comprehensive research done that shows the influence of HRM practices on the satisfaction of employees towards a job.

This study is co-relational type of research design which is aimed to describe or ascertain if there are significant associations between selected HRM practices and employees' job satisfaction.

In addition to Correlation and Regression, Descriptive statistics, frequencies and percentages were utilized to analyze the data. Interpretation is made on the mean, frequency, and percentage of the data and summarized by bar graphs and pie charts.

The study result has implied that recruitment and selection is found to have moderate but positive correlation with employees' job satisfaction and the remaining, training and development, performance appraisal and compensation package found to have strong positive correlation with employees' job satisfaction. Moreover, the regression result shows that recruitment and selection, training and development, performance appraisal and compensation package have a significant positive impact on job satisfaction.

Each HRM practices in the banks should be a source for employees' satisfaction and then employees will be loyal and willing to stay in those organizations (Banks) because, employees' satisfaction on the job will reduce absenteeism and turn over intentions in public banks.

Keywords: Human Resource Management Practices, Job Satisfaction, Public Banks

\section{$(\mathrm{cc}) \mathrm{BY}$}

New articles in this journal are licensed under a Creative Commons Attribution 3.0 United States License.

\section{UILIS D-Sente}

This journal is published by the University Library System of the University of Pittsburgh as part of its D-Scribe Digital Publishing Program, and is cosponsored by the University of Pittsburgh Press. 


\section{The Effect of Selected Human Resource Management Practices on Employees' Job Satisfaction in Ethiopian Public Banks}

\section{Amare Werku Ijigu}

\section{Introduction}

Human resource management is critical to the success of the organizations because human capital has certain qualities that make it valuable. In terms of business strategy, an organization can succeed if it has a sustainable competitive advantage which means better than competitors at something and can hold that advantage over a sustained period of time (Noe et al..., 2007).

Job satisfaction is a factor that would induce the employee to work in the long term position. Regardless of job satisfaction the organization or firm would confront with the cost of recruitment caused by turnover. (Hamdia Mudor \& Phadett Tooksoon, 2011).

Most researches are focused on human resource outcomes of employees such as employee satisfaction, employee commitment, and employee retention due to the changing business environment and organizations are moving towards seeing human resource as a valuable asset in which the knowledge, skills and abilities of human resource is a source of competitive advantages.

According to Armstrong M.(2010) commitment, motivation and job satisfaction, either together or separately, will be higher when people positively experience the application of HR policies concerned with creating an able workforce, motivating valued behaviours and providing opportunities to participate.

In Ethiopia, there are large numbers of employees working on public organizations and most of them are unsure about their satisfaction towards the HRM practices and with the job. Also it is difficult to get published researches that addressed the effect of human resource management practices on employees' job satisfaction in public organizations. In public or state owned banks, the numbers of employees are not quite stable and some employees look on other competent organizations, specifically private companies with in an expectation of better HRM practices, nice work environment and high satisfaction from the job. Every individual employee wants satisfaction at job but organization is wasting its resources by focusing on wrong HR practices for employee job satisfaction (Muhammad Javed, 2012).

Again due to lack of efficient HRM practices reduce employee's satisfaction towards their organization and ultimately that affects their commitment to the organization (Md. Tofael Hossain Majumder, 2012).

\subsection{Research Questions}

In order to achieve the desired purpose and address the problem stated the following research questions were developed. 
$\checkmark$ Which selected human resource management practices affect employees' job satisfaction?

$\downarrow$ How selected human resource management practices impact on employees' job satisfaction?

$\downarrow$ In what ways do selected human resource management practices affect employees' job satisfaction?

\subsection{Objectives of the Study}

The main objective of the study is to investigate the effect of selected human resource management practices on employees' job satisfaction.

The specific objectives of the study are:

$\checkmark$ To measure the degree of association between selected human resource management practices on employees' job satisfaction.

$\checkmark$ To determine which of selected human resource management practices influence on employees' job satisfaction.

$\checkmark$ To assess the effect of selected human resource management practices on employees' job satisfaction.

$\checkmark$ To provide necessary recommendation to the respected public banks based on the results of the study.

\section{Literature Review}

HR practices and job satisfaction are studied widely in different parts of the world. As it is cited by Mir Mohammed Nurul Absar et al.., (2010) it is assumed that HR practices are closely associated with job satisfaction Ting (1997). Because many scholars and practitioners believe that sound HR practices result in better level of job satisfaction which ultimately improves organizational performance (Appelbaum, Bailey, Berg and Kalleberg, 2000) which is cited on Mir Mohammed Nurul Absar et $a l . .,(2010)$.

In human resource management practices (HRMP), individuals most likely have a higher level of communication with co-workers, employees and outsiders of the organization; a greater involvement of in decision making process. It can be said that individuals give high value to these new opportunities, as result their overall job satisfaction might increase when an employee participates in decision-making, he or she can trust his or her supervisors; perceive his or her jobs as challenging and intrinsically rewarding . Trust and intrinsic rewards are in turn positively related to high organizational commitment and positive attitudes toward the job.

Also, as one of the human resource management practices, job rotation might increase employee's job satisfaction by giving him/her a sense of belonging, reducing boredom, and mastering his/her skills needed for promotions (Sarbapriya Ray and Ishita Aditya Ray, 2011). 


\subsection{Outcomes of Previous Empirical Studies}

\begin{tabular}{|c|c|}
\hline Researchers & Findings \\
\hline $\begin{array}{l}\text { Mir } \\
\text { Mohammed } \\
\text { Nurul Absar et } \\
\text { al..., (2010) }\end{array}$ & $\begin{array}{l}\text {-It was found that HR practices have } \\
\text { significant association with job } \\
\text { satisfaction (JS). } \\
\text {-In addition, human resource planning } \\
\text { (HRP), and training and development } \\
\text { (TND) were found to have positive } \\
\text { impact on job satisfaction (JS). } \\
\text {-It was also found that TND has the } \\
\text { greatest impact on JS. }\end{array}$ \\
\hline $\begin{array}{l}\text { Md. Tofael } \\
\text { Hossain } \\
\text { Majumder } \\
(2012)\end{array}$ & $\begin{array}{l}\text {-The study reveals that all HRM } \\
\text { dimensions exercised in the private } \\
\text { banking sector of Bangladesh does not } \\
\text { satisfied to the employees equally. } \\
\text {-Most of the employees are dissatisfied } \\
\text { with compensation package followed by } \\
\text { reward and motivation, career growth, } \\
\text { training and development, management } \\
\text { style, and job design and responsibilities. }\end{array}$ \\
\hline $\begin{array}{l}\text { Sarbapriya } \\
\text { Ray and Ishita } \\
\text { Aditya Ray } \\
\text { (2011) }\end{array}$ & $\begin{array}{l}\text {-It was found that factors like } \\
\text { performance appraisal, participation in } \\
\text { decision making, training and } \\
\text { development, empowerment, } \\
\text { compensation influencing human } \\
\text { resource management( HR) practices } \\
\text { have significant association with job } \\
\text { satisfaction (JS). } \\
\text {-In addition, performance appraisals, } \\
\text { participation in decision making are } \\
\text { found to have high positive impact on } \\
\text { job satisfaction (JS). } \\
\text {-It has also been found that other } \\
\text { elements like training and development, } \\
\text { empowerment, compensation have } \\
\text { substantial impact on employees' job }\end{array}$ \\
\hline
\end{tabular}

\begin{tabular}{|c|c|}
\hline & $\begin{array}{l}\text { satisfaction. } \\
\text {-But, job rotation, self-directed work } \\
\text { teams, recruitment and selection have } \\
\text { very negligible impact on job satisfaction } \\
\text { as their respective t statistics are } \\
\text { insignificant. }\end{array}$ \\
\hline $\begin{array}{l}\text { Adeel Mumtaz } \\
\text { et al..., (2011) }\end{array}$ & $\begin{array}{l}\text {-Result of Study described that teacher } \\
\text { satisfaction is not predicted by these set } \\
\text { of HR practices so there are some other } \\
\text { factor which effect satisfaction. }\end{array}$ \\
\hline $\begin{array}{l}\text { Nihat Kaya et } \\
\text { al.., (2010) }\end{array}$ & $\begin{array}{l}\text {-The study show that in addition to the } \\
\text { positive impact of HRM activities, } \\
\text { organizational climate in particular } \\
\text { makes a significant contribution to job } \\
\text { satisfaction. }\end{array}$ \\
\hline $\begin{array}{l}\text { Hamdia } \\
\text { Mudor and } \\
\text { Phadett } \\
\text { Tooksoon } \\
(2011)\end{array}$ & $\begin{array}{l}\text {-The results indicate HRM practice a } \\
\text { positively and significantly correlated } \\
\text { with job satisfaction. } \\
\text {-HRM practice and job satisfaction are } \\
\text { negatively and significantly correlated } \\
\text { with turnover. } \\
\text { - HRM practice \&job satisfaction are } \\
\text { strong predictors of turnover. }\end{array}$ \\
\hline $\begin{array}{l}\text { Muhammad } \\
\text { Javed et al.., } \\
(2012)\end{array}$ & $\begin{array}{l}\text {-Recognition and training and } \\
\text { development are a key source of } \\
\text { employee job satisfaction in Public } \\
\text { sector organizations of Pakistan but } \\
\text { rewards do not have any significant } \\
\text { impact upon employee job satisfaction. }\end{array}$ \\
\hline $\begin{array}{l}\text { Nausheen } \\
\text { Syed and } \\
\text { Lin Xiao Yan } \\
\text { (2012) }\end{array}$ & $\begin{array}{l}\text {-Empowerment, job rotation, Employee } \\
\text { participation, Merit-based Promotions \& } \\
\text { Performance-based Pay and Grievance } \\
\text { handling procedures, were positively } \\
\text { correlated with employee's job } \\
\text { satisfaction. } \\
\text { - All the practices except Grievance } \\
\text { handling procedures account for unique } \\
\text { variances in job satisfaction of the } \\
\text { surveyed firm's employees. }\end{array}$ \\
\hline
\end{tabular}




\begin{tabular}{|c|c|}
\hline $\begin{array}{l}\text { Alina Ileana } \\
\text { Petrescu and } \\
\text { Rob Simmons } \\
(2008)\end{array}$ & $\begin{array}{l}\text {-After controlling for personal, job and } \\
\text { firm characteristics, it is found that } \\
\text { several HRM practices raise workers' } \\
\text { overall job satisfaction and their } \\
\text { satisfaction with pay. However, these } \\
\text { effects are only significant for non-union } \\
\text { members. } \\
\text {-Satisfaction with pay is higher where } \\
\text { performance-related pay and seniority- } \\
\text { based reward systems are in place. } \\
\text {-A pay structure that is perceived to be } \\
\text { unequal is associated with a substantial } \\
\text { reduction in both non-union members' } \\
\text { overall job satisfaction and their } \\
\text { satisfaction with pay. } \\
\text {-Although HRM practices can raise } \\
\text { workers' job satisfaction, if workplace } \\
\text { pay inequality widens as a consequence } \\
\text { then non-union members may experience } \\
\text { reduced job satisfaction. }\end{array}$ \\
\hline $\begin{array}{l}\text { Rathnaweera } \\
\text { (2010) }\end{array}$ & $\begin{array}{l}\text {-The findings of the research revealed } \\
\text { that Human Resource Management } \\
\text { practices are significant predictors of } \\
\text { employee satisfaction, commitment and } \\
\text { retention. }\end{array}$ \\
\hline
\end{tabular}

\subsection{Conceptual Framework}

The reviewed literature leads to formulate a research model. So, the conceptual framework of the study is:

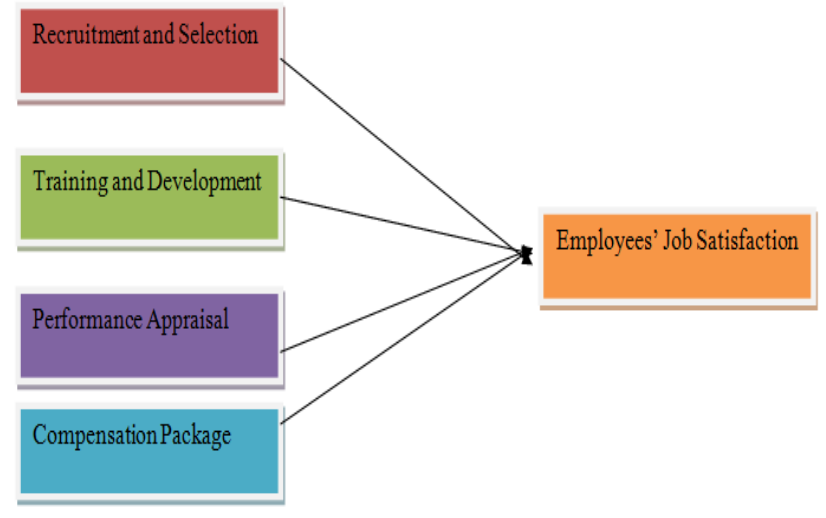

\section{Research Model and Hypotheses}

After looking at the literatures, this research posits the following hypotheses and statistical research model:

H1: Recruitment and selection is significantly and positively related to employee job satisfaction.

H2: Training and Development is significantly and positively related to employee job satisfaction.

H3: Performance Appraisal is significantly and positively related to employee job satisfaction.

H4: Compensation Package is significantly and positively related to employee job satisfaction.

\section{Research Methodology}

\subsection{Research Approach}

The research design that is used for this study is a quantitative research design. The reason for choosing quantitative research design is due to the fact that it involves studies that make use of statistical analyses to obtain their findings. In addition, this study is a correlational type of research design which is aimed to 
describe or ascertain if there are significant associations between selected HRM practices and employees' job satisfaction.

\subsection{Study Variables}

The independent and dependent variables of the study are:

Independent variables -Recruitment and Selection, Training and Development, Performance appraisal and Compensation Package

Dependent variable - Employees' Job Satisfaction

\subsection{Sampling Technique}

As the data obtained from respective public banks, during the year 2012/13 G.C. the overall number of employees working in state owned banks is 16287.

But, by considering geographical restrictions, access to data, expected rate of return from the study and degree of literacy, the study is confined to employees and managers at head office who are at clerical position of the respective banks.

Convenience sampling technique is used to select sample from the target population. The main reason was banks were unable to provide name list of employees within an assumption to keep the confidentiality of the organization. The following formula is used to select the appropriate sample size based on $95 \%$ confidence level and 5\% margin of error or level of precision.

$$
n=\frac{z^{2} \cdot p \cdot q \cdot N}{\mathrm{e}^{2}(\mathrm{~N}-1)+\mathrm{z}^{2} \cdot \mathrm{p} \cdot \mathrm{q}}
$$

Where,

$p=$ sample proportion, $q=1-p ;$

$z=$ the value of the standard variate at a given confidence

level and to be worked out from table showing area under Normal Curve;

$n=$ size of sample.

Source: C.R. Kothari (2004)

Given: At $95 \%$ confidence level the value of $\mathrm{Z}=1.96$

$\mathrm{P}=$ the population proportion (assumed to be .50 since this would provide the maximum sample size).

$\mathrm{N}=2464$ which is population size $\quad \mathrm{e}=$

0.05 which is acceptable sample error

$$
\begin{gathered}
n=\frac{1.96^{2}(0.5)(0.5)(2464)}{0.05^{2}(2464-1)+1.96^{2}(0.5)(0.5)}=332.461203 \\
n \approx 333
\end{gathered}
$$

So, based on the above formula a sample of 333 is selected from the target population and participated in the study which was a sample of both employees and managers.

The sample size obtained is allocated to three banks proportional to their population size.

\subsection{Method of Data Collection}

The study used both primary and secondary sources of data. Primary data is obtained through questionnaire that is collected from employees and managers at the head offices of the respective public banks.

Questionnaire is prepared for employees and managers. A five point Likert Scale questionnaire is used to measure the 
variables of the study. Some of the questionnaire item was adapted from past researches; (Rathnaweera, 2010) and (Nihat Kaya et al..., 2010) which are better to describe the variables under study.

Secondary data was gathered from published and unpublished theoretical literatures and empirical studies, books, journal articles, internet and other publications.

\subsection{Method of Data Analysis}

Quantitative data analysis tools are used to analyse the collected data. Descriptive statistics are used to describe and interpret the results of the study. Correlation analysis more specifically Pearson correlation coefficient is used to measure the degree of association between selected HRM practices and employees' job satisfaction. From inferential statistics, Regression analysis is used to test the hypothesis of the study.

\subsection{Reliability and Validity}

The reliability statistics result of both employees and managers questionnaires respectively are excellent and good based on different literature.

Regarding to validity, Validation of questionnaire item is carried out through initial consultation of experts to judge the research instrument.

\section{Discussion of Findings}

\subsection{Descriptive Statistics}

The mean scores for recruitment and selection was greater than the rest four variables indicating that respondents are satisfied with the recruitment and selection practice. But the mean scores for the rest four variables are closer to three (3) indicating respondents are neutral or moderate in their satisfaction with the respective variables. The standard deviations for the five variables ranged from 0.71230 to 1.02899 indicating that the data were reasonably homogenous.

\subsection{Correlation Analysis}

Despite the correlation coefficient of recruitment and selection is weaker compared with other variables, training and development, performance appraisal and compensation package all are found to be strongly and positively correlated with dependent variable job satisfaction. The value $(r=0.365)$ suggests that the strength of recruitment and selection is moderate but positively correlated with job satisfaction, $\quad(r=0.677)$ shows that training and development is strongly and positively correlated with job satisfaction, $(r=0.713)$ shows that performance appraisal is strongly and positively correlated with job satisfaction and $(r=0.802)$ shows that compensation package is strongly and positively related with job satisfaction.

\subsection{Regression Analysis}

Results of linear regression analysis indicated that $13 \%$ variance in employee job satisfaction is explained by recruitment and selection, which is evident by the value of $\mathrm{R}=0.365 \quad \mathrm{~F}=39.247$ at $p<0.01$ illustrates the model's goodness of fit, the regression result also confirms that 
recruitment and selection is a significant predictor of job satisfaction $(\mathrm{Beta}=0.365, \mathrm{t}=6.265, \mathrm{p}<0.01)$.

Thus, the null hypothesis is rejected and the alternative hypothesis that 'Recruitment and selection is significantly and positively related to employee job satisfaction' is failed to reject.

Results of linear regression analysis indicated that $45.6 \%$ variance in employee job satisfaction is explained by training and development, which is evident by the value of $\mathrm{R}=0.677 \mathrm{~F}=215.942$ at $p<0.01$ illustrates the model's goodness of fit, the regression result also confirms that training and development is a significant predictor of job satisfaction $($ Beta $=0.677, \mathrm{t}=14.695, \mathrm{p}<0.01)$.

Thus, the null hypothesis is rejected and the alternative hypothesis that 'Training and Development is significantly and positively related to employee job satisfaction' is failed to reject.

Results of linear regression analysis indicated that $50.6 \%$ variance in employee job satisfaction is explained by performance appraisal, which is evident by the value of $\mathrm{R}=0.713 \mathrm{~F}=263.064$ at $p<0.01$ illustrates the model's goodness of fit, the regression result also confirms that performance appraisal is a significant predictor of job satisfaction $(\mathrm{Beta}=0.713, \mathrm{t}=16.219, \mathrm{p}<0.01)$.

Thus, the null hypothesis is rejected and the alternative hypothesis that 'Performance Appraisal is significantly and positively related to employee job satisfaction' is failed to reject.

Results of linear regression analysis indicated that $64.2 \%$ variance in employee job satisfaction is explained by compensation package, which is evident by the value of
$\mathrm{R}=0.802 \mathrm{~F}=460.094$ at $p<0.01$ illustrates the model's goodness of fit, the regression result also confirms that compensation package is a significant predictor of job satisfaction $(\operatorname{Beta}=0.802, \mathrm{t}=21.450, \mathrm{p}<0.01)$. Thus, the null hypothesis is rejected and the alternative hypothesis that 'Compensation Package is significantly and positively related to employee job satisfaction' is failed to reject.

\section{Conclusion and Recommendation}

\subsection{Conclusion}

The results of this study revealed that bundles of HRM practices mainly recruitment and selection, training and development, performance appraisal and compensation package are positively related to employee job satisfaction. This result is consistent with Mir Mohammed Nurul Absar et al..., (2010) and Rathnaweera (2010). This means that effective HRM practices lead to employee satisfaction.

\subsection{Recommendation}

The overall goal and objectives of the banks would be achieved if and only if employees are satisfied with the job. This will be achieved through by each HRM practices in the banks should be a source for employees satisfaction and then employees will be loyal and willing to stay in that organizations (Banks) because, job satisfaction of employees will reduce absenteeism and turn over intentions in public banks. Moreover, the need and expectations of employees' also play a vital role in increasing employees' satisfaction through by implementing two way 
communications and then by continually evaluating the human resource management practices of the banks as well.

\section{Recommendation}

Public banks should revise and make an adjustment on certain rules and procedures that hinders the employees not to perform with their maximum effort since it has an effect on employees' level of satisfaction.

It is recommended that the management of respective public banks should be able to increase the level of commitment in banks by increasing satisfaction with the specified HRM practices.

Each public bank has to create a link between the recruitment and selection practices and employees job satisfaction by preparing job descriptions and specifications; deciding terms and conditions of employment; reviewing and evaluating alternative sources of applicants, inside and outside the banks and should take other necessary measurements as well.

\section{Suggestions for Future Research}

The study sample is mainly focused on head office employees of respective public banks. So, future researchers can take sample of city and outlying or regional branch employees and managers. Furthermore, the study is basically intended to examine the effect of some of HRM practices such as recruitment and selection, training and development, performance appraisal and compensation package on employees' job satisfaction. Potential researchers can study by considering further HRM practices whether or not they have an impact on employees' job satisfaction. Finally, the study is emphasized on banking industry specifically on public banks. Others researcher can study on private banks and confirm whether or not HRM practices have an effect on employees' job satisfaction. 


\section{REFERENCES}

Abel G/tsadik. (2012). The Effect of Reward

System on Job Satisfaction: The Case

of Commercial Bank of Ethiopia Addis

Ababa Area. Unpublished Master's

Thesis, Addis Ababa University.

Adeel Mumtaz, Imran Khan, Hassan Danial Aslam and Bashir Ahmad. (2011). Impact of $\mathrm{HR}$ Practices on job Satisfaction of University Teacher: Evidence from Universities in Pakistan. Industrial Engineering Letters, 1, 1017.

Alina Ileana Petrescu and Rob Simmons. (2008). Human resource management practices and workers' job satisfaction. International Journal of Manpower, 29, $651-667$.

Anol Bhattacherjee. (2012). Social Science Research: Principles, Methods and $\underline{\text { Practices. }} 2^{\text {nd }}$ ed. USA: Creative Commons Attribution 3.0

Armstrong, M. (2006). A Handbook of Human Resource Management. $10^{\text {th }}$ ed. Great Britain and USA: Kogan Page Limited.

Armstrong, M. (2009). Armstrong's Handbook of Human Resource Management
Practice. $11^{\text {th }}$ ed. London: Great Britain and USA: Kogan Page Limited.

Armstrong, M. (2010). Armstrong's Essential

Human Resource Management

Practice: A Guide to People

Management. Great Britain and USA:

Kogan Page Limited.

Armstrong, M., Duncan Brown. (2006).

Strategic Reward: Making It Happen.

Great Britain and USA: Kogan Page

Limited.

Asta Savaneviciene \& Zivile Stankeviciute. (2011). Human Resource Management Practices Linkage with Organizational Commitment and Job Satisfaction. Economics And Management, 16, 921 928

C.R. Kothari. (2004). Research Methodology: Methods and Techniques. Second Revised Edition. New Delhi: New Age International (P) Ltd.

Cynthia, D., Fisher, Lyle, F. Schoenfeldt and James, B. Shaw. (2006). Human Resource Management. $6^{\text {th }}$ ed. USA: Houghton Mifflin Company.

Gary Dessler. (2004). A Framework for HRM. $3^{\text {th }}$ ed, New Jersey: Pearson Education, Inc. 
Gary Dessler. (2005). Human Resource Management. $10^{\text {th }}$ ed, USA: Pearson Prentice Hall.

Geoffrey Marczyk, David DeMatteo and David Festinger. (2005). Essentials of $\underline{\text { Research Design and Methodology. }}$ New Jersey: John Wiley \& Sons, Inc.

Hamdia Mudor \& Phadett Tooksoon. (2011). Conceptual framework on the relationship between human resource management practices, job satisfaction, and turnover. Journal of Economics and Behavioral Studies, 2, 41-49

Helen Collins. (1993). Human Resource Management: Personnel Policies and Procedures. Great Britain: Hodder and Stoughton Educational

Hirut G/Kidan. (2011). The Effect of Compensation Strategies on Employees Job Satisfaction The Case of Ethiopian Federal Democratic Republic $\underline{\text { HIV/AIDS Prevention and Control }}$ office (FHAPCO) and Dink Kistet Letena (DKT) Ethiopia. Unpublished Master's thesis, Addis Ababa University.
John M. Ivancevich. (2008). Human Resource Management. $10^{\text {th }}$ ed, India: Tata McGraw - Hill Companies, Inc.

John Storey. (2007). Management: A Critical Context, $3^{\text {rd }}$ ed. Thomson.

Louis Cohen, Lawrence Manion and Keith Morrison. (2007). Research Methods in Education. $6^{\text {th }}$ ed. Taylor \& Francis eLibrary

Md. Tofael Hossain Majumder. (2012). Human Resource Management Practices and Employees' Satisfaction towards Private Banking Sector in Bangladesh. $\underline{\text { International Review of Management }}$ and Marketing, 2, 52-58

Mengiste Kassa. (2012). Human Resource Development Practices in Commercial Bank of Ethiopia. Unpublished Master's Thesis, Addis Ababa University.

Mir Mohammed Nurul Absar, Mohammad Tahlil Azim, Nimalathasan Balasundaram, Sadia Akhter. (2010). Impact of Human Resources Practices on Job Satisfaction: Evidence from Manufacturing Firms in Bangladesh. 
Economic Sciences Series, LXII, 31-

42.

Muhammad Javed, Muhammad Rafiq, Maqsood Ahmed and Mustajab Khan. (2012). Impact of HR Practices on Employee Job Satisfaction in Public Sector Organizations of Pakistan. Interdisciplinary Journal of

Contemporary Research in Business, 4 , 348-363.

Muhammad Javed, Muhammad Rafiq, Maqsood Ahmed and Mustajab Khan. (2012). Impact of HR Practices on Employee Job Satisfaction in Public Sector Organizations of Pakistan. Interdisciplinary Journal of Contemporary Research in Business, 4 , 348-363.

Nausheen Syed and Lin Xiao Yan. (2012). Impact of high performance Human Resource Management Practices on Employee Job Satisfaction: Empirical Analysis. Interdisciplinary Journal of Research in Business, $4,318-342$.

Nihat Kaya, Erdogan Koc and Demet Topcu. (2010). An exploratory analysis of the influence of human resource management activities and organizational climate on job satisfaction in Turkish banks. The International Journal of Human

Resource Management, 21, 2031-2051.

Phyllis Tharenou, Ross Donuhue and Brian Cooper. (2007). Management Research Methods. New York: Cambridge University Press.

R. Wayne., Mondy, Robert, M. Noe and Shane, R. Premeaux. (1999). Human Resource Management. $7^{\text {th }}$ ed. New Jersey: Prentice Hall, Inc.

Raigama Rathnaweerage Neelamani Thanuja Rathnaweera (2010). Do HRM Practices Impact Employee Satisfaction, Commitment Or $\underline{\text { Retention? Empirical Studies of Sri }}$ Lankan Public Sector Banks. Unpublished Master's Thesis, University of Agder.

Raymond, A. Noe., John, R. Hollenbeck., Barry, Gerhart and Patrick M. Wright (2007). Fundamentals of Human

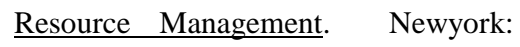
McGraw - Hill Companies, Inc.

Robbins, S.P. (1998). Organizational Behavior: Concepts, Controversies and Applications, $\quad 8^{\text {th }}$ ed. Newyork: Prentice-Hall, Inc. 
Robert L. Mathis and John H. Jackson. (1994).

Human Resource Management. $7^{\text {th }}$ ed. West Publishing Corporation.

Samy Tayie (Prof. PhD). (2005). ㄹesearch Methods and Writing Research Proposals. Center for Advancement of Post Graduate Studies and Research in Engineering Science, Faculty of Engineering - Cairo University (CAPSCU)

Sarbapriya Ray \& Ishita Aditya Ray. (2011). Human Resource Management Practices and Its Effect on Employees' Job Satisfaction: A Study on Selected Small and Medium Sized Iron \&Steel Firms in India. Public Policy and Administration Research, 1, 22-33.

Stephen P. Robbins. (2005). Essentials of Organizational Behavior. $8^{\text {th }}$ ed, New Jersey: Pearson Education, Inc.

Tofael Hossain Majumder, Md. (2012). Human Resource Management Practices and Employees' Satisfaction towards Private Banking Sector in Bangladesh. International Review of Management and Marketing, 2, 52-58.
Torrington, D., Hall, L. and Taylor, S. (2008). Human Resource Management. $7^{\text {th }}$ ed. England: Pearson Education Limited.

Wendell L. French. (1990). Human Resource Management. $2^{\text {nd }}$ ed, USA: Houghton Mifflin Company.

\section{Websites}

http://wiki.answers.com/Q/Define_publ

ic_sector_bank accessed date $16^{\text {th }}$

February 2012

http://en.wikipedia.org/wiki/Job_satisfa ction accessed on many times 
Appendix

Table 4.7.1. Reliability Test Result of Study Variables

Reliability Statistics result of Employees Questionnaire

\begin{tabular}{|l|l|}
\hline Cronbach's Alpha & N of Items \\
\hline .955 & 41 \\
\hline
\end{tabular}

Reliability Statistics result of Managers questionnaire

\begin{tabular}{|l|l|}
\hline Cronbach's Alpha & N of Items \\
\hline 821 & 13 \\
\hline
\end{tabular}

Table 5.1.1. Mean and Standard Deviation of the Five Study

Variables

\begin{tabular}{|l|l|l|l|l|l|}
\hline $\begin{array}{l}\text { Statist } \\
\text { ics }\end{array}$ & $\begin{array}{l}\text { Recruit } \\
\text { ment } \\
\text { and } \\
\text { Selecti } \\
\text { on }\end{array}$ & $\begin{array}{l}\text { Training } \\
\text { and } \\
\text { Develop } \\
\text { ment }\end{array}$ & $\begin{array}{l}\text { Perform } \\
\text { ance } \\
\text { Apprais } \\
\text { al }\end{array}$ & $\begin{array}{l}\text { Compen } \\
\text { sation } \\
\text { Package }\end{array}$ & $\begin{array}{l}\text { Job } \\
\text { Satisfa } \\
\text { ction }\end{array}$ \\
\hline Mean & 3.9326 & 3.3781 & 3.1740 & 3.0832 & 3.3160 \\
\hline $\begin{array}{l}\text { Std. } \\
\text { Devia } \\
\text { tion }\end{array}$ & $\begin{array}{l}0.7123 \\
0\end{array}$ & 0.89106 & 1.02899 & 0.98726 & $\begin{array}{l}0.8477 \\
8\end{array}$ \\
\hline
\end{tabular}

Table 5.2.1. Correlation Result of Recruitment and Selection and Employees' Job Satisfaction

Correlations

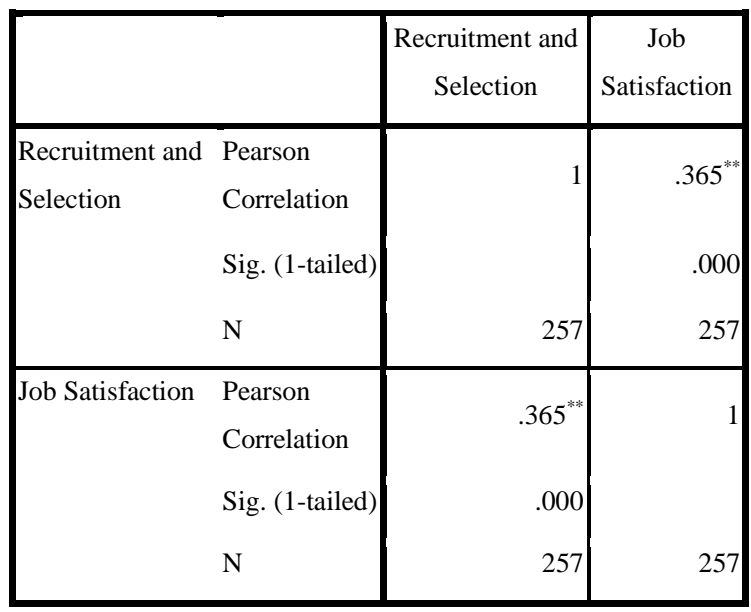

Correlations

\begin{tabular}{|c|c|c|c|}
\hline & & $\begin{array}{c}\text { Recruitment and } \\
\text { Selection }\end{array}$ & $\begin{array}{c}\text { Job } \\
\text { Satisfaction }\end{array}$ \\
\hline $\begin{array}{l}\text { Recruitment and } \\
\text { Selection }\end{array}$ & $\begin{array}{l}\text { Pearson } \\
\text { Correlation } \\
\text { Sig. (1-tailed) } \\
\text { N }\end{array}$ & $\begin{array}{r}1 \\
257\end{array}$ & $\begin{array}{r}.365^{* *} \\
.000 \\
257\end{array}$ \\
\hline Job Satisfaction & $\begin{array}{l}\text { Pearson } \\
\text { Correlation } \\
\text { Sig. (1-tailed) } \\
\mathrm{N}\end{array}$ & $\begin{array}{r}.365^{* *} \\
.000 \\
257\end{array}$ & 257 \\
\hline
\end{tabular}

**. Correlation is significant at the 0.01 level (1tailed).

Table 5.2.2. Correlation Result of Training and

Development Employees' Job Satisfaction

Correlations

\begin{tabular}{|c|c|c|c|}
\hline & & $\begin{array}{l}\text { Training and } \\
\text { Development }\end{array}$ & $\begin{array}{c}\text { Job } \\
\text { Satisfaction }\end{array}$ \\
\hline $\begin{array}{l}\text { Training and } \\
\text { Development }\end{array}$ & $\begin{array}{l}\text { Pearson } \\
\text { Correlation } \\
\text { Sig. (1-tailed) } \\
\mathrm{N}\end{array}$ & \begin{tabular}{r|}
1 \\
257
\end{tabular} & $\begin{array}{r}.677^{* *} \\
.000 \\
257\end{array}$ \\
\hline Job Satisfaction & $\begin{array}{l}\text { Pearson } \\
\text { Correlation } \\
\text { Sig. (1-tailed) } \\
\mathrm{N}\end{array}$ & $\begin{array}{c}.677^{* *} \\
.000 \\
257\end{array}$ & 257 \\
\hline
\end{tabular}

Amare Werku Ijigu

Emerging Markets Journal | P a g e |13 
Table 5.2.3. Correlation Result of Performance Appraisal and Employees' Job Satisfaction

Correlations

\begin{tabular}{|c|c|c|c|}
\hline & & $\begin{array}{c}\text { Performance } \\
\text { Appraisal }\end{array}$ & $\begin{array}{c}\text { Job } \\
\text { Satisfaction }\end{array}$ \\
\hline $\begin{array}{l}\text { Performance } \\
\text { Appraisal }\end{array}$ & $\begin{array}{l}\text { Pearson } \\
\text { Correlation } \\
\text { Sig. (1-tailed) } \\
\mathrm{N}\end{array}$ & \begin{tabular}{r|}
1 \\
257
\end{tabular} & $\begin{array}{l}.713^{* *} \\
.000 \\
257\end{array}$ \\
\hline Job Satisfaction & $\begin{array}{l}\text { Pearson } \\
\text { Correlation } \\
\text { Sig. (1-tailed) } \\
\mathrm{N}\end{array}$ & $\begin{array}{c}.713^{* *} \\
.000 \\
257\end{array}$ & 257 \\
\hline
\end{tabular}

**. Correlation is significant at the 0.01 level (1-

tailed).

Table 5.2.4. Correlation Result of Compensation Package and Employees' Job Satisfaction

Correlations

\begin{tabular}{|ll|r|r|}
\hline & & $\begin{array}{c}\text { Compensation } \\
\text { Package }\end{array}$ & \multicolumn{1}{|c|}{$\begin{array}{c}\text { Job } \\
\text { Satisfaction }\end{array}$} \\
\hline Compensation & Pearson & 1 & $.802^{* *}$ \\
& Correlation & & .000 \\
& Sig. (1-tailed) & & 257 \\
& $\mathrm{~N}$ & 257 & 1 \\
\hline Job Satisfaction & Pearson & $.802^{* *}$ & \\
& Correlation & .000 & \\
& Sig. (1-tailed) & 257 & 257 \\
& N & & \\
\hline
\end{tabular}

**. Correlation is significant at the 0.01 level (1tailed).
Table 5.3.1. Regression Result of Recruitment and Selection and Employees' Job Satisfaction

Model Summary

\begin{tabular}{|l|r|r|r|r|}
\hline Model & \multicolumn{1}{|c|}{$\mathrm{R}$} & R Square & $\begin{array}{c}\text { Adjusted R } \\
\text { Square }\end{array}$ & $\begin{array}{r}\text { Std. Error of } \\
\text { the Estimate }\end{array}$ \\
\hline 1 & $.365^{\mathrm{a}}$ & .133 & .130 & .79077 \\
\hline
\end{tabular}

a. Predictors: (Constant), Recruitment and Selection

\section{ANOVA $^{b}$}

\begin{tabular}{|l|r|r|r|r|r|}
\hline Model & $\begin{array}{l}\text { Sum of } \\
\text { Squares }\end{array}$ & Df & $\begin{array}{r}\text { Mean } \\
\text { Square }\end{array}$ & F & Sig. \\
\hline 1 Regression & 24.542 & 1 & 24.542 & 39.247 & $.000^{\mathrm{a}}$ \\
Residual & 159.455 & 255 & .625 & & \\
Total & 183.997 & 256 & & & \\
\hline
\end{tabular}

a. Predictors: (Constant),

Recruitment and Selection

b. Dependent Variable: Job

Satisfaction

Coefficients $^{\mathrm{a}}$

\begin{tabular}{|c|c|c|c|c|c|}
\hline \multirow[b]{2}{*}{ Model } & \multicolumn{2}{|c|}{$\begin{array}{c}\text { Unstandardized } \\
\text { Coefficients }\end{array}$} & \multirow{2}{*}{$\begin{array}{c}\text { Standardized } \\
\text { Coefficients } \\
\text { Beta }\end{array}$} & \multirow[b]{2}{*}{$\mathrm{t}$} & \multirow[b]{2}{*}{ Sig. } \\
\hline & B & $\begin{array}{l}\text { Std. } \\
\text { Error }\end{array}$ & & & \\
\hline $\begin{array}{l}1 \text { (Constant) } \\
\text { Recruitment and } \\
\text { Selection }\end{array}$ & 1.607 & .277 & .365 & 5.794 & .000 \\
\hline
\end{tabular}


ANOVA $^{b}$

\begin{tabular}{|l|r|r|r|r|r|}
\hline Model & $\begin{array}{l}\text { Sum of } \\
\text { Squares }\end{array}$ & Df & Square & F & Sig. \\
\hline 1 Regression & 24.542 & 1 & 24.542 & 39.247 & $.000^{\mathrm{a}}$ \\
Residual & 159.455 & 255 & .625 & & \\
Total & 183.997 & 256 & & & \\
\hline
\end{tabular}

a. Dependent Variable: Job

Satisfaction

Table 5.3.2. Regression Result of Training and Development and Employees' Job Satisfaction

Model Summary

\begin{tabular}{|r|r|r|r|r|}
\hline Model & \multicolumn{1}{|c|}{$\mathrm{R}$} & R Square & \multicolumn{1}{c|}{$\begin{array}{c}\text { Adjusted R } \\
\text { Square }\end{array}$} & $\begin{array}{l}\text { Std. Error of } \\
\text { the Estimate }\end{array}$ \\
\hline 1 & $.677^{\mathrm{a}}$ & .459 & .456 & .62506 \\
\hline
\end{tabular}

$\operatorname{ANOVA}^{\mathrm{b}}$

\begin{tabular}{|l|r|r|r|r|r|}
\hline Model & $\begin{array}{l}\text { Sum of } \\
\text { Squares }\end{array}$ & df & $\begin{array}{r}\text { Mean } \\
\text { Square }\end{array}$ & F & Sig. \\
\hline 1 Regression & 84.369 & 1 & 84.369 & 215.942 & $.000^{\mathrm{a}}$ \\
Residual & 99.629 & 255 & .391 & & \\
Total & 183.997 & 256 & & & \\
\hline
\end{tabular}

a. Predictors: (Constant), Training

and Development

b. Dependent Variable: Job

Satisfaction
Coefficients $^{\mathrm{a}}$

\begin{tabular}{|c|c|c|c|c|c|}
\hline \multirow[b]{2}{*}{ Model } & \multicolumn{2}{|c|}{$\begin{array}{c}\text { Unstandardized } \\
\text { Coefficients }\end{array}$} & \multirow{2}{*}{$\begin{array}{c}\text { Standardized } \\
\text { Coefficients } \\
\text { Beta }\end{array}$} & \multirow[b]{2}{*}{$\mathrm{t}$} & \\
\hline & B & Error & & & Sig. \\
\hline 1 (Constant) & 1.140 & .153 & & 7.441 & .000 \\
\hline $\begin{array}{l}\text { Training and } \\
\text { Development }\end{array}$ & .644 & .044 & .677 & 14.695 & .000 \\
\hline
\end{tabular}

a. Dependent Variable: Job

Satisfaction

Table 5.3.3. Regression Result of Performance Appraisal and Employees' Job Satisfaction

Model Summary

\begin{tabular}{|r|r|r|r|r|}
\hline Model & \multicolumn{1}{|c|}{$\mathrm{R}$} & R Square & $\begin{array}{c}\text { Adjusted R } \\
\text { Square }\end{array}$ & $\begin{array}{l}\text { Std. Error of } \\
\text { the Estimate }\end{array}$ \\
\hline 1 & $.713^{\mathrm{a}}$ & .508 & .506 & .59596 \\
\hline
\end{tabular}

a. Predictors: (Constant), Performance Appraisal

ANOVA

\begin{tabular}{|l|r|r|r|r|r|}
\hline Model & $\begin{array}{l}\text { Sum of } \\
\text { Squares }\end{array}$ & df & Square & F & Sig. \\
\hline $1 \quad$ Regression & 93.431 & 1 & 93.431 & 263.064 & $.000^{a}$ \\
Residual & 90.567 & 255 & .355 & & \\
Total & 183.997 & 256 & & & \\
\hline
\end{tabular}

a. Predictors: (Constant), Performance

Appraisal 
ANOVA $^{b}$

\begin{tabular}{|l|r|r|r|r|r|}
\hline Model & $\begin{array}{r}\text { Sum of } \\
\text { Squares }\end{array}$ & df & $\begin{array}{r}\text { Mean } \\
\text { Square }\end{array}$ & F & Sig. \\
\hline $1 \quad$ Regression & 93.431 & 1 & 93.431 & 263.064 & $.000^{\mathrm{a}}$ \\
Residual & 90.567 & 255 & .355 & & \\
Total & 183.997 & 256 & & & \\
\hline
\end{tabular}

b. Dependent Variable: Job

Satisfaction

Coefficients $^{\mathrm{a}}$

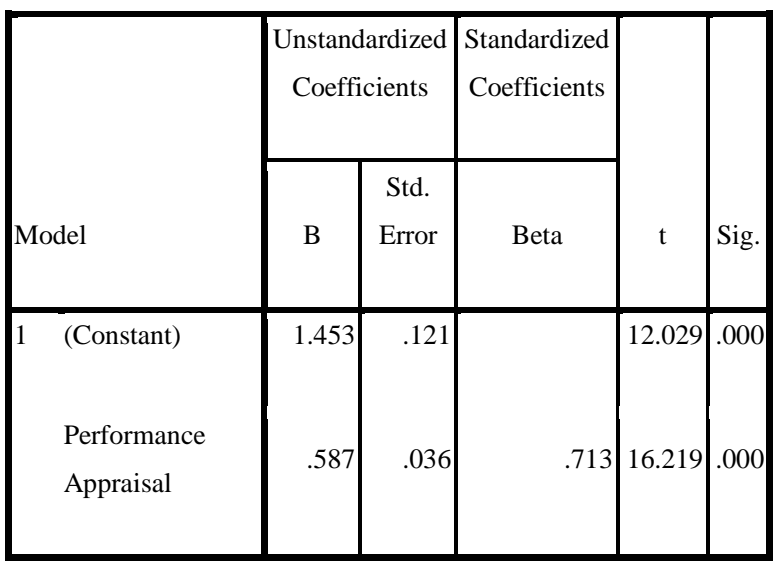

a. Dependent Variable: Job

Satisfaction

Table 5.3.4. Regression Result of Compensation Package and Employees' Job Satisfaction

Model Summary

\begin{tabular}{|l|r|r|r|r|}
\hline Model & \multicolumn{1}{|c|}{$\mathrm{R}$} & R Square & $\begin{array}{c}\text { Adjusted R } \\
\text { Square }\end{array}$ & $\begin{array}{r}\text { Std. Error of } \\
\text { the Estimate }\end{array}$ \\
\hline 1 & $.802^{\mathrm{a}}$ & .643 & .642 & .50725 \\
\hline
\end{tabular}

ANOVA $^{\mathrm{b}}$

\begin{tabular}{|l|r|r|r|r|r|}
\hline Model & $\begin{array}{r}\text { Sum of } \\
\text { Squares }\end{array}$ & df & $\begin{array}{c}\text { Mean } \\
\text { Square }\end{array}$ & F & Sig. \\
\hline 1 Regression & 118.384 & 1 & 118.384 & 460.094 & $.000^{\mathrm{a}}$ \\
Residual & 65.613 & 255 & .257 & & \\
Total & 183.997 & 256 & & & \\
\hline
\end{tabular}

a. Predictors: (Constant), Compensation

Package

b. Dependent Variable: Job

Satisfaction

Coefficients $^{\mathrm{a}}$

\begin{tabular}{|c|c|c|c|c|c|}
\hline & $\begin{array}{r}\text { Unstand } \\
\text { Coeffi }\end{array}$ & $\begin{array}{l}\text { ardized } \\
\text { cients }\end{array}$ & $\begin{array}{l}\text { Standardized } \\
\text { Coefficients }\end{array}$ & & \\
\hline Model & B & $\begin{array}{l}\text { Std. } \\
\text { Error }\end{array}$ & Beta & $\mathrm{t}$ & Sig. \\
\hline $\begin{array}{l}1 \text { (Constant) } \\
\text { Compensation } \\
\text { Package }\end{array}$ & 1.192 & .104 & .802 & $\begin{array}{l}11.471 \\
21.450\end{array}$ & .000 \\
\hline
\end{tabular}

a. Dependent Variable: Job

Satisfaction 